\title{
Effects of different hydrocolloids on the texture profile of chicken meat emulsions
}

\author{
Tomaz Polak', Mateja Lusnic Polak', Igor Lojevec ${ }^{1}$,Lea Demsar*l
}

A b s tr a c $t$ : The aim of the study was to produce chicken breast meat emulsions with the addition of different hydrocolloids that would have comparable, or better, textural properties to those produced with phosphates (E 450-452). We prepared 10 emulsions from mechanically separated chicken breast meat (as three experimental repetitions) with the additions of: phosphates (control; $0.7 \%$ ), and three different levels of one each of carrageenan, xanthan (these additives were used at $0.5 \%, 0.8 \%$ and $1 \%$ levels) or potato starch $(1 \%, 1.5 \%, 2 \%)$. Instrumental measurements of colour (CIE $\left.L^{*}, a^{*}, b^{*}\right)$ and texture (texture profile analysis, stress relaxation tests) were performed, along with evaluation of the sensory attributes (descriptive analysis). These chicken breast meat emulsions with different hydrocolloids significantly differed in their instrumentally measured colour values and most texture parameters (hardness, cohesiveness, gumminess, chewiness, resilience, $F_{0}, Y_{30}$ ), and in some of the sensory attributes (colour, firmness, aroma). The increases in carrageenan and potato starch additions affected some of the measured colour values and the sensory attributes, although the measured texture parameters were not affected. The increases in xanthan addition showed changes in the colour, texture and sensory profiles. Those chicken breast meat emulsions with phosphate (0.7\%), carrageenan (0.5\%, 0.8\%) and potato starch (2.0\%) were the most similar in colour, texture and aroma. Those with potato starch showed non-significant trends for improved attributes compared to the control group, due to their intense aroma.

Keywords: meat emulsions, phosphate, hydrocolloids, texture parameters, sensory properties.

\section{Introduction}

Over the last 30 years or so, the search has gone on for solutions to replace the addition of phosphates to meat (e.g., E 338-452), one of the most widely used additives in the meat industry (Feiner, 2006). Phosphates have very wide applications in the meat industry, as they can improve water binding, and in connection with the salts included, they can stabilise the texture of meat products. As a consequence, phosphates can increase the solubility of proteins, act as chelators, prevent the oxidation (and rancidity) of lipids, and inhibit the growth of certain microorganisms (Feiner, 2006; Fonseca et al., 2011).

Accordingly, the addition of phosphates to fresh or processed meat and sausages increases the water holding capacity, and thus, the amount of water in the product. This will directly reduce production costs for the product. Therefore, due to the possibility of misrepresenting a meat product by inclusion of high levels of water, producers are limited by law in terms of the addition of phosphates to meat products (European Union, 2008). Also, excessive uptake of phosphate by the body can lead to deterioration of human health (Ellam and Chico, 2011). Furthermore, meat products with high levels of added phosphates can show deterioration of some of the sensory attributes, accompanied in particular by an unpleasant soap-like and astringent flavour, as well as a tougher and more rubbery texture (Sebranek, 2009).

For these reasons, phosphates are often substituted by, or used in combination with, carrageenan (Barbut and Mittal, 1992; Trius and Sebranek, 1996; Pietrasik and Duda, 2000; Amako and Xiong, 2001; Pietrasik, 2003; Ayadi et al., 2009; Cierach et al., 2009; Chun et al., 2014; Gao et al., 2016), xanthan (Palaniraj and Jayaraman, 2011), alginate, casein or sodium caseinate, gelatin, guar gum, carob gum and arabic gum, hydrolysed plant proteins, starch (Liu et al., 2008; Inguglia et al., 2017), carboxymethyl cellulose, glucomannans, xyloglucan, white melon or yellow mustard (Sinapis alba L.), and other such substitutes (BeMiller in Huber, 2011; Brewer, 2012; Tamsen et al., 2018). Indeed, from the health and sensory point of view, phosphate substitutes continue to be sought intensively, with positive

'University of Ljubljana, Biotechnical Faculty, Jamnikarjeva 101, 1000 Ljubljana, Republic of Slovenia.

*Corresponding author: Lea Demsar, lea.demsar@bf.uni-lj.si 
results mainly seen for the use of hydrocolloids and modified starches.

The aim of the present study was to produce meat emulsions by addition of different substitutes for phosphates, to achieve similar, or even better, textural properties compared to the equivalent meat emulsion produced using phosphates. For this purpose, we prepared 10 groups of chicken breast meat emulsions that included the phosphate mixture (control) plus three different concentrations of three different hydrocolloids: carrageenan, xanthan and potato starch.

\section{Materials and Methods}

\section{Materials}

Mechanically deboned chicken breast meat was obtained from Pivka Perutninarstvo (Pivka Poultry; Kal, Slovenia), which was stored at $-2.3^{\circ} \mathrm{C}$ and used $30 \mathrm{~h}$ after slaughter. According to the nutrition declaration of the producer, $100 \mathrm{~g}$ of the chicken breast meat contained mean levels of $14.07 \mathrm{~g}$ protein, $20.12 \mathrm{~g}$ fat, $63.99 \mathrm{~g}$ water, and $1.65 \mathrm{~g}$ collagen.

The further materials used included: sunflower oil (Cekin brand; Tovarna olja Gea, Slovenska Bistrica, Slovenia); nitrite salt $(0.6 \% \mathrm{Na}$ nitrite; Prava Aroma, Zrkovci, Slovenia); seasoning mixture for special salami (Etol, Skofja vas, Slovenia); phosphate mixture (Aroma Universal K; Prava Aroma, Zrkovci, Slovenia); carrageenan (E 407a and $\mathrm{NaCl}$; Aubygel RPI 1010; Cargill, Minneapolis, USA); dextrose (dextrose monohydrate; CDex 02044; Cargill, Minneapolis, USA); sodium erythorbate (E 316; RFI Food Ingredients, Düsseldorf, Germany); xanthan (E 415; Jungbunzlauer, Wulzeshofe, Austria); and potato starch (CGel 30002; Cargill, Minneapolis, USA).

The phosphate mixture had a composition of dextrose, phosphates (E 450, E 451) and sodium erythorbate (E 316), at a weight ratio of 355: 300: 45, respectively.

\section{Preparation of chicken breast meat emulsion}

The chicken breast meat emulsions were produced with addition of phosphates (control), carrageenan (E 407a), xanthan (E 415) or potato starch. The control emulsion was made from $75 \%$ mechanically deboned chicken breast meat, 5\% sunflower oil, $20 \%$ ice, $1.5 \%$ nitrite salt, $0.7 \%$ phosphate mixture, and $0.3 \%$ seasoning mixture. Another nine groups of meat emulsions were produced based on these raw materials and additives, whereby instead of the phosphate mixture, the different hydrocolloids were added to provide three different levels, low, medium and high, as detailed in Table 1. As the

Table 1. Extra additions to the chicken breast meat emulsions for the different experimental groups.

All samples included 75\% mechanically deboned chicken breast meat, 5.0\% sunflower oil, $20.0 \%$ ice, $1.5 \%$ nitrite salt, and $0.3 \%$ seasoning mixture.

\begin{tabular}{lccccc}
\hline Group & \multicolumn{5}{c}{ Extra addition (\%) } \\
\cline { 2 - 6 } & $\begin{array}{c}\text { Phosphate } \\
\text { mixture }\end{array}$ & $\begin{array}{c}\text { Dextrose }+ \\
\text { Na-erythorbate }\end{array}$ & Carrageenan & Xanthan & Potato starch \\
\hline Control (phosphate) & 0.70 & - & - & - & - \\
Carrageenan & - & 0.40 & 0.5 & - & - \\
& - & 0.40 & 0.8 & - & - \\
& - & 0.40 & 1.0 & - & - \\
Xanthan & - & 0.40 & - & 0.5 & - \\
& - & 0.40 & - & 0.8 & - \\
& - & 0.40 & - & 1.0 & - \\
Potato starch & - & 0.40 & - & - & 1.0 \\
& - & 0.40 & - & - & 1.5 \\
& - & 0.40 & - & - & 2.0 \\
\hline
\end{tabular}


phosphate mixture included dextrose and sodium erythorbate as well as the phosphates, the same levels of dextrose and sodium erythorbate were added to the remaining nine experimental groups.

Mechanically deboned chicken meat, nitrite salt, phosphate mixture (control group) or each level of hydrocolloid with dextrose and sodium erythorbate, and half of the ice were homogenised (Stephan UMC 5 electronic; Stephan Nahrungsmittel und Verfahrenstechnik, Hameln, Germany) at $2400 \mathrm{rpm}$ until an internal temperature of $6^{\circ} \mathrm{C}$ was reached. Then the sunflower oil, seasoning mixture, and the other half of the ice were added, with further homogenisation at $2400 \mathrm{rpm}$ until an internal temperature of $11.9^{\circ} \mathrm{C}$ was reached. The emulsions formed were used to fill plastic casings (diameter, $4 \mathrm{~cm}$; length, $10 \mathrm{~cm}$ ). All of the samples were simultaneously thermally treated in a cooking chamber (Fessmann $\mathrm{GmbH}$ und Co KG, Winnenden, Germany) until the final temperature of $72^{\circ} \mathrm{C}$, then cooled and stored at $4^{\circ} \mathrm{C}$ until the sensory and physico-chemical analyses. The experiment was performed as three repetitions.

\section{Chemical composition analysis}

The chemical compositions of the chicken breast meat emulsions were determined using a meat analyser (Food Scan Meat Analyser; Foss, Hilleroed, Denmark). On the basis of the near-infrared absorption technique, the meat analyser provided information on the content of water, protein, fat and salt in these meat products. Nitrite was determined by the AOAC Official Method 973.31 for nitrite in cured meats $(A O A C, 1997)$. The data obtained are expressed as the means of two parallel determinations per sample, where the samples originated from experimental groups of the first experimental repetition, as control, $0.5 \%, 0.8 \%$ and $1.0 \%$ carrageenan, $0.5 \%, 0.8 \%$ and $1.0 \%$ xanthan, and $1.0 \%, 1.5 \%$ and $2.0 \%$ potato starch.

\section{Colour analysis}

A chromometer (Minolta CR-400; Konica Minolta Optics, Inc., Osaka, Japan; illuminant $\mathrm{C}, 0^{\circ}$ viewing angle) was used to determine the Commission Internationale de l'Eclairage (CIE; International Commission on Illumination) $L^{*}$ (lightness), $a^{*}$ ( \pm , red to green) and $b^{*}$ ( \pm , yellow to blue) values for the surface of a $1-\mathrm{cm}$ slice of each chicken breast meat emulsion. A white ceramic tile with the specifications of $\mathrm{Y}=93.8, \mathrm{x}=0.3134, \mathrm{y}=0.3208$ was used to standardise the colorimeter. The CIE $L^{*}, a^{*}$ and $b^{*}$ colour values are given as the means of four measured at different locations on the slice surface.
Texture profile analysis and stress relaxation test

The textural parameters were measured using a texture analyser (TA.XT Plus; Stable Micro Systems Ltd., Surrey, UK) with a permissible load of $50 \mathrm{~kg}$. Texture profile analysis and stress relaxation tests were carried out on the chicken breast meat emulsions (without the plastic casings). Sample preparation for the texture profile analysis and stress relaxation tests were based on Morales et al. (2007). The samples were cut into 3 -cm-high cylinders. The diameters of the cylinders ranged from $3.9 \mathrm{~mm}$ to $4.0 \mathrm{~mm}$. For the contact attachment, a $100-\mathrm{mm}$ cylindrical probe (P100) was used. For the texture profile analysis, the samples were compressed twice to $50 \%$ of their original length (with $5 \mathrm{~s}$ between these compression cycles) and at a crosshead speed of $5 \mathrm{~mm} \mathrm{~s}^{-1}$, with analyses repeated as four determinations. The force versus time curves were recorded, and the following parameters were calculated: hardness, adhesiveness, cohesiveness, gumminess, springiness, chewiness and resilience. For the stress relaxation tests, the samples were compressed to $50 \%$ of their original length at a crosshead speed of $1 \mathrm{~mm} \mathrm{~s}^{-1}$. The force decay, or relaxation, versus time after compression was recorded, and the relaxation curves were normalised according to the level of force decay $Y(t)$ defined in Equation (1):

$$
Y(t)=\left(F_{0}-F(t)\right) / F_{0}
$$

where $F_{0}(\mathrm{~kg})$ is the initial force, and $F(t)$ is the decaying force recorded after $t \mathrm{~s}$ of relaxation (Moralles et al., 2006).

\section{Sensory analysis}

To evaluate the sensory qualities of these chicken breast meat emulsions, a panel of four qualified and experienced panellists in the field of meat products was appointed (Gasperlin et al., 2014). The evaluations were carried out under defined, precisely prescribed, and controlled and reproducible operating conditions. This included: arrangement of the laboratory, samples and accessories, and organisation of the assessment (ISO 8589, 2007).

The samples were taken out of the refrigerator and left at room temperature so that the temperature of the slices during analysis was $\sim 15^{\circ} \mathrm{C}$. For the sensory evaluation, 1-cm-thick slices of the samples were prepared, placed on white ceramic plates, and given to the panellists. The plates were equipped with a number, thus ensuring the anonymity of the samples. To neutralise the taste, the panel used the central dough of white bread. Sensory analysis was carried out in three sessions (one for each experimental repetition), organised on three consecutive days. 
On the basis of preliminary tasting for the purpose of the evaluation, the panel decided in favour of, and applied, an analytical-descriptive test (Golob et al., 2005). The analysis was performed by scoring the sensory attributes on a structured scale from 1 to 7 points, where a higher score indicated greater expression of a given property. The exception here was saltiness, which was evaluated by scoring on a structured scale of 1 to 4 to 7 (1-4-7). Here, a score of 4 points was considered optimal, with scores of 4.5 or higher indicating greater expression of saltiness, and those of 3.5 or lower indicating insufficient expression of saltiness. These sensory profiles of the emulsion samples were assessed using five descriptors that were grouped into four blocks: appearance, texture, smell and aroma.

\section{Statistical analysis}

The data were tested for normal distributions using the UNIVARIATE procedure (SAS/STAT, USA). The differences according to additive in different levels were analysed through a general linear model procedure and Duncan tests, with a $0.05 \mathrm{lev}$ el of significance. In evaluating these data, the impact of the experimental repetitions was also taken into account, as this effect was significant for most of these analysed parameters $(\mathrm{p} \leq 0.05)$, and was thus included in the statistical model.

\section{Results and Discussion}

The basic chemical parameters were determined in parallel for the four main experimental groups (i.e., control, carrageenan, xanthan, potato starch), as produced in the first repetition. The mean contents of $100 \mathrm{~g}$ of the chicken breast meat emulsions were $10.52 \pm 0.16 \mathrm{~g}$ protein, $19.28 \pm 0.68 \mathrm{~g}$ fat, $66.14 \pm 0.34 \mathrm{~g}$ water, and $0.88 \pm 0.10 \mathrm{~g}$ salt, with residual nitrite at $0.112 \pm 0.003 \mathrm{~g}$. The homogeneity of the experimental groups was confirmed on the basis of the corresponding standard deviations.

The instrumentally measured $a^{*}$ value (i.e., shade of red colour) on the surface of the chicken breast meat emulsions was the colour parameter that varied the most across the samples (coefficient of variability, $4.4 \%$ ). The colours of these emulsions were significantly affected by the type and level of hydrocolloid additions. As all of these experimental groups of the chicken breast meat emulsions contained the same levels of nitrite salt (1.5\%), these differences in colour were due to the type and quantity of each of the hydrocolloids added.
The data given in Table 2 for the $L^{*}$ value show that this was lower (i.e., darker emulsions) for the addition of carrageenan $(0.8 \%, 1.0 \%)$ and starch (all levels), compared to the control and the other groups (i.e., 0.5\% carrageenan; xanthan, all levels). Mittal and Barbut (1994) reported that xanthan addition to frankfurters increased the $L^{*}$ value. Generally, the colour parameters of the $0.5 \%$ carrageenan and $0.5 \%$ and $1.0 \%$ xanthan groups remained close to the control group.

Texture profile analysis (Bourne, 1978) and stress relaxation tests (Pons and Fiszman, 1996) are the methods that are most frequently used for evaluation of the textural properties of foods. The rheological behaviour of foods, including the texture, can be studied using several instrumental methods (e.g., compression, torsion, tension, stress). At present, the most commonly used are Warner-Bratzler tests and texture profile analysis, which are based on measurements of sample compression. Texture profile analysis parameters have already been obtained for meat products in many previous studies (e.g., de Ávila et al., 2014). Furthermore, the effects of the types and levels of the additives used in the present

Table 2. Effects of the different levels of the hydrocolloids on the instrumentally measured colour parameters of the surfaces of slices of the chicken breast meat emulsions $(n=120)$.

\begin{tabular}{lcccc}
\hline Group & Level & \multicolumn{3}{c}{ Colour parameter } \\
\cline { 3 - 5 } & $(\%)$ & $\boldsymbol{L}^{*}$ & $\boldsymbol{a}^{*}$ & $\boldsymbol{b}^{*}$ \\
\hline Control & 0.7 & $71.17^{\mathrm{ba}}$ & $13.72^{\mathrm{b}}$ & $11.85^{\mathrm{c}}$ \\
Carrageenan & 0.5 & $69.77^{\mathrm{c}}$ & $14.09^{\mathrm{a}}$ & $12.25^{\mathrm{a}}$ \\
& 0.8 & $69.86^{\mathrm{c}}$ & $13.83^{\mathrm{ba}}$ & $12.25^{\mathrm{a}}$ \\
& 1.0 & $70.97^{\mathrm{b}}$ & $13.19^{\mathrm{dc}}$ & $11.89^{\mathrm{c}}$ \\
Xanthan & 0.5 & $71.67^{\mathrm{a}}$ & $13.29^{\mathrm{c}}$ & $12.18^{\mathrm{ba}}$ \\
& 0.8 & $71.70^{\mathrm{a}}$ & $12.47^{\mathrm{e}}$ & $12.24^{\mathrm{a}}$ \\
& 1.0 & $71.18^{\mathrm{ba}}$ & $13.04^{\mathrm{d}}$ & $12.31^{\mathrm{a}}$ \\
Potato starch & 1.0 & $69.59^{\mathrm{c}}$ & $14.04^{\mathrm{a}}$ & $11.95^{\mathrm{c}}$ \\
& 1.5 & $69.90^{\mathrm{c}}$ & $14.05^{\mathrm{a}}$ & $12.03^{\mathrm{bc}}$ \\
& 2.0 & $70.56^{\mathrm{b}}$ & $13.42^{\mathrm{c}}$ & $12.03^{\mathrm{bc}}$ \\
SE & - & 0.23 & 0.09 & 0.06 \\
$\mathrm{p}_{\mathrm{A}}$ & - & $\leq 0.001$ & $\leq 0.001$ & $\leq 0.001$ \\
\hline
\end{tabular}

Legend: $n$, number of observations in experiment; $p_{A}$, statistical probability of addition effect; means with different superscript letters within columns differ significantly ( $\mathrm{p} \leq 0.05$; significance of differences between groups) 
Table 3. Effects of the different levels of the hydrocolloids on the instrumentally measured texture profile analysis parameters of the chicken breast meat emulsions $(n=120)$.

\begin{tabular}{|c|c|c|c|c|c|c|c|c|}
\hline \multirow[t]{2}{*}{ Group } & \multirow{2}{*}{$\begin{array}{l}\text { Level } \\
(\%)\end{array}$} & \multicolumn{7}{|c|}{ Texture profile analysis parameter } \\
\hline & & $\begin{array}{l}\text { Hardness } \\
\text { (N) }\end{array}$ & $\begin{array}{l}\text { Adhesiveness } \\
\text { (N s) }\end{array}$ & Springiness & Cohesiveness & $\begin{array}{l}\text { Gumminess } \\
\text { (N) }\end{array}$ & $\begin{array}{c}\text { Chewiness } \\
\text { (N) }\end{array}$ & Resilience \\
\hline Control & & $124.1^{\text {ba }}$ & -1.88 & 0.90 & $0.71^{\mathrm{a}}$ & $87.55^{\mathrm{a}}$ & $78.89^{\mathrm{a}}$ & $0.39^{\mathrm{a}}$ \\
\hline \multirow[t]{3}{*}{ Carrageenan } & 0.5 & $130.1^{\mathrm{a}}$ & -3.47 & 0.86 & $0.65^{\text {ba }}$ & $84.14^{\mathrm{a}}$ & $72.45^{\text {ba }}$ & $0.33^{\mathrm{b}}$ \\
\hline & 0.8 & $131.0^{\mathrm{a}}$ & -2.07 & 0.87 & $0.61^{\text {ba }}$ & $78.33^{\mathrm{abc}}$ & $68.36^{\text {bdac }}$ & $0.30^{\mathrm{b}}$ \\
\hline & 1.0 & $126.8^{\mathrm{a}}$ & -1.92 & 0.88 & $0.64^{\text {ba }}$ & $80.47^{\mathrm{ab}}$ & $70.76^{\text {bdac }}$ & $0.31^{\mathrm{b}}$ \\
\hline \multirow[t]{3}{*}{ Xanthan } & 0.5 & $108.4^{\mathrm{bc}}$ & -2.12 & 0.87 & $0.61^{\text {ba }}$ & $66.15^{\mathrm{dc}}$ & $58.17^{\mathrm{dc}}$ & $0.32^{\mathrm{b}}$ \\
\hline & 0.8 & $117.5^{\text {ba }}$ & -1.70 & 0.89 & $0.56^{\mathrm{b}}$ & $64.24^{\mathrm{d}}$ & $57.55^{\mathrm{d}}$ & $0.29^{\mathrm{b}}$ \\
\hline & 1.0 & $66.3^{\mathrm{d}}$ & -1.87 & 0.86 & $0.42^{\mathrm{c}}$ & $27.38^{\mathrm{e}}$ & $23.47^{\mathrm{e}}$ & $0.18^{c}$ \\
\hline \multirow[t]{3}{*}{ Potato starch } & 1.0 & $120.9^{\text {ba }}$ & -2.66 & 0.89 & $0.68^{\mathrm{a}}$ & $81.47^{\text {ba }}$ & $72.86^{\text {ba }}$ & $0.34^{b}$ \\
\hline & 1.5 & $104.6^{\mathrm{bc}}$ & -1.81 & 0.91 & $0.73^{\mathrm{a}}$ & $75.86^{\mathrm{abc}}$ & $69.08^{\text {bac }}$ & $0.36^{\mathrm{b}}$ \\
\hline & 2.0 & $114.8^{\mathrm{ba}}$ & -1.53 & 0.88 & $0.69^{\mathrm{a}}$ & $79.98^{\text {ba }}$ & $71.51^{\mathrm{bac}}$ & $0.33^{b}$ \\
\hline SE & & 19.0 & 1.57 & 0.09 & 0.11 & 15.68 & 14.97 & 0.06 \\
\hline $\mathrm{p}_{A}$ & & $\leq 0.001$ & 0.093 & 0.844 & $\leq 0.001$ & $\leq 0.001$ & $\leq 0.001$ & $\leq 0.001$ \\
\hline
\end{tabular}

Legend: $n$, number of observations in experiment; $\mathrm{p}_{A}$, statistical probability of addition effect; means with different superscript letters within columns differ significantly ( $\mathrm{p} \leq 0.05$; significance of differences between groups)

study were significantly different $(\mathrm{p} \leq 0.001)$ across the texture profile analyses (Table 3 ), including for hardness, cohesiveness, gumminess, chewiness and resilience. However, the adhesiveness and springiness of the chicken breast meat emulsions were not significantly affected by the different hydrocolloid additions ( $\mathrm{p}>0.05)$.

When Marchetti et al. (2013) added carrageenan and xanthan into meat emulsions that contained oil, higher levels of aggregates were formed and the matrix was more interconnected. This was reflected in their higher cohesiveness compared to the emulsions produced solely with bacon, without the addition of these hydrocolloids. In the present study, however, compared to the control, none of the additions of carrageenan or potato starch (all levels for both) affected the cohesiveness. However, the cohesiveness of our emulsions was significantly lower for the additions of $0.8 \%$ and $1.0 \%$ xanthan. Marchetti et al. (2013) also reported that the addition of carrageenan or xanthan into meat emulsions with oil produced products with similar hardness compared to their control with solely bacon. They stated that the filling matrix was enhanced due to the gelatin capacity of these biopolymers. In the case of carrageenan and starch addition into meat emulsions, the gumminess and chewiness did not vary significantly compared to the control, but these properties were generally reduced by addition of xanthan.

The stress relaxation test takes into account the viscoelastic nature of a sample. Although there are no data on the use of the stress relaxation tests on poultry emulsions, the test has been used satisfactorily for other products, such as gels (Peleg and Pollak, 1982), fish (Herrero et al., 2004) and hot dogs (Skinner and Rao, 1986). Most foods are biologically active or physically unstable, and their mechanical properties can change significantly over a very short period of time, which can greatly limit the use of tests such as the stress relaxation test. Indeed, this test applies a certain force for a long time during the analysis; e.g., for $30 \mathrm{~s}$ to $90 \mathrm{~s}$ (Peleg and Pollak, 1982; Purkayastha and Peleg, 1986). From the data for the present study given in Table 4, it can be seen that all of the carrageenan additions increased $F_{0}$ (i.e., the initial pressing force), and generally, the xanthan additions decreased $F_{0}$ compared to the control. This is in agreement with the findings from other studies (Bater et al., 1992; Mittal and Barbut, 1994; Hsu and Chung, 2001). The $F_{0}$ of those chicken breast meat emulsions with potato starch were comparable $(1.0 \%, 1.5 \%)$ or higher $(2.0 \%)$ than the control. 
The quantitative descriptive analysis of the sensory attributes of these 10 experimental chicken breast meat emulsion groups indicated that the phosphate (control) and the type and level of the added hydrocolloids affected the perceived colour, firmness and aroma. On the contrary, all of these groups of emulsions were estimated to have similar juiciness and smell, and appropriate saltiness (Table 5).

The panellists estimated that compared to the control group, the chicken breast meat emulsions with the low level of added carrageenan $(0.5 \%)$ and all levels of potato starch were the most similar for colour, while $0.8 \%$ and $1.0 \%$ carrageenan and all levels of xanthan were less successful (Table 5). As is known from the literature, the addition of carrageenan, xanthan and starch affects the texture, and therefore, the finding that perceived firmness of our chicken breast meat emulsions with the various additions showed differences was not surprising. However, although increasing the level of carrageenan did not change the texture, the panellists described the effects of the increased levels

Table 4. Effects of the different levels of the hydrocolloids on the instrumentally measured texture parameters in the stress relaxation tests of the chicken breast meat emulsions $(n=120)$.

\begin{tabular}{lccc}
\hline \multirow{2}{*}{ Group } & Level & \multicolumn{2}{c}{$\begin{array}{c}\text { Stress relaxation test } \\
\text { parameter }\end{array}$} \\
\cline { 3 - 4 } & $(\mathbf{\%})$ & $\boldsymbol{F}_{\boldsymbol{0}}$ & $\boldsymbol{Y}_{30}$ \\
\hline Control & 0.7 & $95.91^{\mathrm{cd}}$ & $0.33^{\mathrm{a}}$ \\
Carrageenan & 0.5 & $104.82^{\mathrm{b}}$ & $0.37^{\mathrm{b}}$ \\
& 0.8 & $100.11^{\mathrm{bc}}$ & $0.36^{\mathrm{ab}}$ \\
& 1.0 & $119.56^{\mathrm{a}}$ & $0.36^{\mathrm{ab}}$ \\
Xanthan & 0.5 & $103.31^{\mathrm{bc}}$ & $0.37^{\mathrm{b}}$ \\
& 0.8 & $88.08^{\mathrm{ef}}$ & $0.37^{\mathrm{b}}$ \\
Potato starch & 1.0 & $47.63^{\mathrm{g}}$ & $0.70^{\mathrm{c}}$ \\
& 1.0 & $92.36^{\mathrm{de}}$ & $0.36^{\mathrm{ab}}$ \\
& 1.5 & $102.78^{\mathrm{bc}}$ & $0.36^{\mathrm{ab}}$ \\
SE & 2.0 & $84.49^{\mathrm{f}}$ & $0.36^{\mathrm{ab}}$ \\
$\mathrm{p}_{A}$ & & 4.87 & 0.02 \\
\hline
\end{tabular}

Legend: $n$, number of observations in experiment; $F_{0}$, initial force; $Y_{30}$, force decay level after $30 \mathrm{~s} ; \mathrm{p}_{A}$, statistical probability of addition effect; means with different superscript letters within columns differ significantly ( $\mathrm{p} \leq 0.05$; significance of differences between groups) of xanthan as providing a softer and more fragile emulsion; indeed, for $1.0 \%$ xanthan, these effects even became unacceptable. In contrast, $2.0 \%$ potato starch made the texture of the emulsion firmer.

Increases in the hardness of meat products have been reported previously when carrageenan was added, also at $0.2 \%$ and $0.5 \%$ (Barbut and Mittal, 1992; Xiong et al., 1999; Hsu and Chung, 2001; Ayadi et $a l ., 2009)$. These studies are, thus, in good agreement with the findings in the present study, both in terms of the sensory assessments and the instrumentally measured hardness of the emulsions. The addition of xanthan to food depends on the density and the desired consistency of the food. In the present study, the panellists described the texture of xanthan emulsions as soft, plastic and fragile. It can be assumed here that xanthan was used at too high a level (i.e., $0.8 \%, 1.0 \%$ ), as addition of $0.2 \%$ to $0.5 \%$ xanthan have usually been used for the production of meat emulsions (Palaniraj and Jayaraman, 2011).

The conclusions reached by the panellists about the aroma of these chicken breast meat emulsions were interesting. The aroma of the control group was assessed as worse than optimum due to a perceived soap-like aroma. The aroma of these emulsions with added starch at all levels was evaluated as the best, although this did not reach statistical significance. Comparable, but slightly worse (although also not statistically significant), aromas were assessed for those emulsions with added carrageenan and xanthan at all levels, which is not surprising, as carrageenan leaves an unusual off-aroma in the mouth, which was described by the panellists as bitter. These assessments are in agreement with findings of Ayadi et al. (2009), who also reported the addition of carrageenan does not significantly affect the aroma of sausages. In the available literature, there is a report that the addition of xanthan can also have negative effects on the sensory acceptability of sausages (Barbut and Mittal, 1992).

Of note here, both of the instrumental texture parameter tests provided satisfactory data, as the correlation analysis of the parameters obtained demonstrated the suitability of both of these methods (Table 6). Overall, however, the stress relaxation test might be more suitable for measurement of the texture of meat emulsions with various additions of hydrocolloids, such as those used in our study.

\section{Multivariate analysis}

Linear discriminant analysis was performed to define these experimental groups of chicken breast meat emulsions on the basis of the parameters that differed the most or those that contributed most to the 
Table 5. Effects of the different levels of the hydrocolloids on the sensory attributes of the chicken breast meat emulsions $(\mathrm{n}=120)$.

\begin{tabular}{|c|c|c|c|c|c|c|c|}
\hline \multirow[t]{2}{*}{ Group } & \multirow{2}{*}{$\begin{array}{l}\text { Level } \\
(\%)\end{array}$} & \multicolumn{6}{|c|}{ Sensory property (intensity) } \\
\hline & & $\begin{array}{c}\text { Colour } \\
(1-7)\end{array}$ & $\begin{array}{c}\text { Firmness } \\
\quad(1-7)\end{array}$ & $\begin{array}{c}\text { Juiciness } \\
\text { (1-7) }\end{array}$ & $\begin{array}{c}\text { Saltiness } \\
(1-4-7)\end{array}$ & $\begin{array}{c}\text { Smell } \\
(1-7)\end{array}$ & $\begin{array}{c}\text { Aroma } \\
(1-7)\end{array}$ \\
\hline Control & 0.7 & $6.1^{\mathrm{a}}$ & $5.1^{\mathrm{b}}$ & 6.2 & 4.0 & 5.9 & $5.6^{\mathrm{bac}}$ \\
\hline \multirow[t]{3}{*}{ Carrageenan } & 0.5 & $6.0^{\mathrm{a}}$ & $5.5^{\text {ba }}$ & 6.0 & 4.0 & 6.0 & $5.6^{\mathrm{bac}}$ \\
\hline & 0.8 & $5.7^{\mathrm{bc}}$ & $5.5^{\mathrm{ba}}$ & 6.0 & 4.0 & 5.8 & $5.5^{\mathrm{bc}}$ \\
\hline & 1.0 & $5.5^{\mathrm{dc}}$ & $5.5^{\mathrm{ba}}$ & 5.9 & 4.0 & 5.7 & $5.4^{\mathrm{bc}}$ \\
\hline \multirow[t]{3}{*}{ Xanthan } & 0.5 & $5.3^{\mathrm{d}}$ & $4.6^{\mathrm{c}}$ & 5.9 & 4.0 & 5.7 & $5.5^{\mathrm{bac}}$ \\
\hline & 0.8 & $5.5^{\mathrm{dc}}$ & $4.4^{\mathrm{c}}$ & 6.0 & 4.0 & 5.8 & $5.5^{\mathrm{bac}}$ \\
\hline & 1.0 & $5.5^{\mathrm{dc}}$ & $3.4^{\mathrm{d}}$ & 6.2 & 4.0 & 5.8 & $5.3^{\mathrm{c}}$ \\
\hline \multirow[t]{3}{*}{ Potato starch } & 1.0 & $6.0^{\mathrm{a}}$ & $5.5^{\text {ba }}$ & 6.0 & 4.0 & 5.8 & $5.8^{\mathrm{ba}}$ \\
\hline & 1.5 & $5.8^{\text {ba }}$ & $5.2^{\mathrm{b}}$ & 6.0 & 4.0 & 5.9 & $5.7^{\mathrm{ba}}$ \\
\hline & 2.0 & $5.8^{\mathrm{ba}}$ & $5.7^{\mathrm{a}}$ & 6.1 & 4.1 & 5.9 & $5.8^{\mathrm{a}}$ \\
\hline SE & & 0.1 & 0.2 & 0.2 & 0.1 & 0.1 & 0.1 \\
\hline $\mathrm{p}_{A}$ & & $<0.0001$ & $<0.0001$ & 0.812 & 0.781 & 0.419 & 0.041 \\
\hline
\end{tabular}

Legend: $\mathrm{n}$, number of observations in experiment; $\mathrm{p}_{A}$, statistical probability of addition effect; means with different superscript letters within columns differ significantly ( $\mathrm{p} \leq 0.05$; significance of differences between groups)

similarities within each defined group (i.e., the addition of phosphate or hydrocolloids). The 16 parameters grouped in the three blocks were included in this analysis, as the instrumentally measured parameters of colour and texture, and the sensory attributes.

This linear discriminant analysis defined the following parameters as being the most discriminating: gumminess, chewiness, firmness, hardness, $Y_{30}$ and $a^{*}$ value. In all (i.e., 120 samples, 16 variables), nine discriminant functions were obtained. Function 1 explained $52 \%$ of the total variance, function 2 explained $23 \%$, function 3 explained $8 \%$ and function 4 explained $7 \%$; the other functions together explained $6 \%$ of the total variance.

Table 6. Relationships between the instrumental measurements and the sensory evaluations of the texture profiles (Pearson correlation coefficient, $r)$ of the chicken breast meat emulsions $(n=120)$.

\begin{tabular}{lcccc}
\hline Instrumental & Parameter & $\begin{array}{c}\text { Sensory analysis } \\
\text { for firmness }\end{array}$ & \multicolumn{2}{c}{ Stress relaxation test } \\
\cline { 4 - 5 } & Hardness & $0.42^{* *}$ & $\boldsymbol{F}_{\boldsymbol{0}}$ & $\boldsymbol{Y}_{30}$ \\
\hline Texture profile & Adhesiveness & -0.03 & $0.66^{* *}$ & $0.74^{* *}$ \\
analysis & Springiness & 0.09 & -0.01 & 0.07 \\
& Cohesiveness & $0.43^{* *}$ & 0.14 & 0.39 \\
& Gumminess & $0.53^{* *}$ & $0.47^{* *}$ & $0.66^{* *}$ \\
& Chewiness & $0.51^{* *}$ & $0.67^{* *}$ & $0.79^{* *}$ \\
Stress relaxation & Resilience & $0.43^{* *}$ & $0.61^{* *}$ & $0.77^{* *}$ \\
test & $F_{0}$ & $0.68^{* *}$ & $0.53^{* *}$ & $0.75^{* *}$ \\
\hline
\end{tabular}

Legend: $n$, number of observations in experiment; ${ }^{*} \mathrm{p} \leq 0.05 ;{ }^{* *} \mathrm{p} \leq 0.001 ; \mathrm{F}_{0}$ initial force; $\mathrm{Y}_{30}$ force decay level after $30 \mathrm{~s}$ 


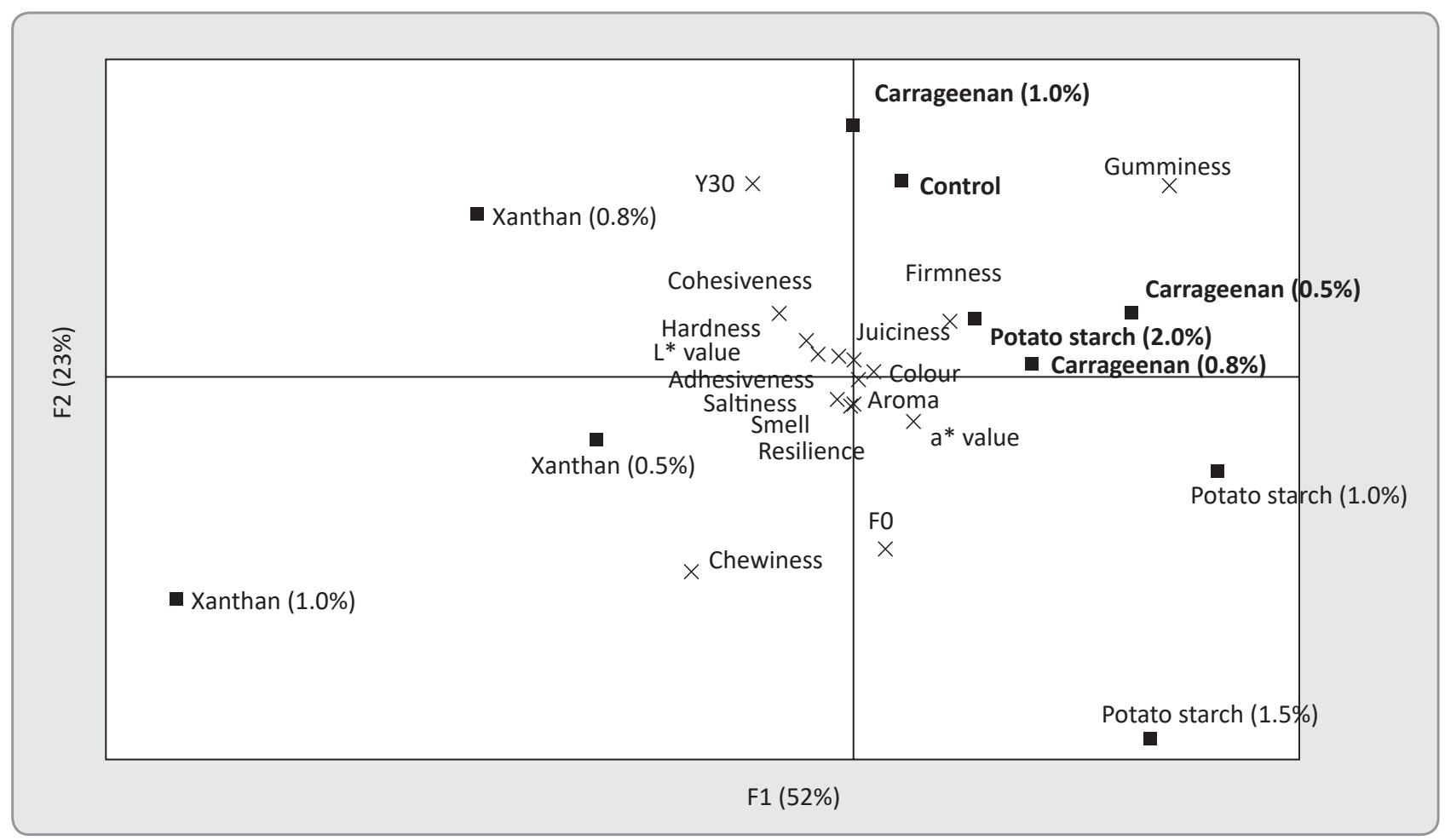

Figure 1. Linear discriminant analysis for the scores for the properties defined by principal component analysis for the 10 groups of chicken breast meat emulsions: additions of phosphate and the hydrocolloids,

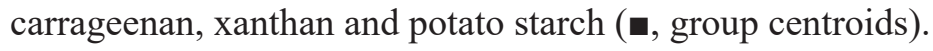

Figure 1 shows the effects of the attributes of the two main functions. Function 1 clearly distinguished a group of variables that was positioned far from the origin, which included gumminess and perceived firmness. These variables were negatively correlated with chewiness, which function 1 positioned on the opposite side. Function 2 essentially grouped the textural variables, with $Y_{30}$, cohesiveness and hardness positioned furthest from the origin; function 2 positioned $F_{0}$ on the opposite side. Smell, aroma and saltiness were positioned close to each other, thus showing high positive correlations.

This analysis divided the chicken breast meat emulsions into three separate profiles that were clearly noted: the first profile that comprised the control (phosphate) group and the additions of carrageenan (all levels) and potato starch (2.0\%); the second profile that comprised the potato starch $1.0 \%$ and $1.5 \%$ groups; and the third profile that comprised the additions of xanthan (all levels). Specific importance can be given to the first profile that included the control chicken breast meat emulsion along with the emulsions with carrageenan and potato starch (at the highest levels), which were defined on the basis of the 16 parameters discussed that grouped these together close to the control.
Overall, the accuracy of the placement of each sample into its corresponding group was $75 \%$, where 30 observations out of 120 were misplaced (Table 7). Here, three observations from the potato starch $2.0 \%$ group were placed with the controls; two observations from the control group were placed with the carrageenan $0.5 \%$ group and one with the potato starch $1.0 \%$ group. These misplaced samples confirmed the similarities of the low carrageenan $(0.5 \%)$ and high potato starch $(2.0 \%)$ groups to the control group, and for the medium xanthan $(0.8 \%)$ and low potato starch (1.0\%) groups (Table 7).

\section{Conclusions}

These data support the hypothesis that chicken breast meat emulsions with added phosphates or different hydrocolloids can differ significantly according to their instrumentally measured colour and texture parameters and their sensorial qualities. The differences across these parameters are not always dependent on the type of additive, but are rather the result of the levels of the hydrocolloids used in the emulsions. Overall, it can be said that generally there were no changes in the instrumentally measured textures (with the exception of $F_{0}$ ), 
Table 7. Classification matrix for the control and experimental groups of the chicken breast meat emulsions according to the linear discriminant analysis.

\begin{tabular}{|c|c|c|c|c|c|c|c|c|c|c|c|c|}
\hline \multirow[t]{3}{*}{ Group } & \multirow{3}{*}{$\begin{array}{c}\text { Level } \\
(\%)\end{array}$} & \multicolumn{10}{|c|}{ Predicted group membership } & \multirow[t]{3}{*}{ Total } \\
\hline & & \multirow[t]{2}{*}{ Control } & \multicolumn{3}{|c|}{ Carrageenan (\%) } & \multicolumn{3}{|c|}{ Xanthan (\%) } & \multicolumn{3}{|c|}{ Potato starch (\%) } & \\
\hline & & & 0.5 & 0.8 & 1.0 & 0.5 & 0.8 & 1.0 & 1.0 & 1.5 & 2.0 & \\
\hline Control & & 9 & 2 & 0 & 0 & 0 & 0 & 0 & 1 & 0 & 0 & 12 \\
\hline \multirow[t]{3}{*}{ Carrageenan } & 0.5 & 0 & 10 & 1 & 0 & 0 & 0 & 0 & 1 & 0 & 0 & 12 \\
\hline & 0.8 & 0 & 2 & 9 & 1 & 0 & 0 & 0 & 0 & 0 & 0 & 12 \\
\hline & 1.0 & 0 & 0 & 0 & 9 & 1 & 1 & 0 & 0 & 0 & 1 & 12 \\
\hline \multirow[t]{3}{*}{ Xanthan } & 0.5 & 0 & 0 & 0 & 0 & 10 & 0 & 1 & 0 & 0 & 1 & 12 \\
\hline & 0.8 & 1 & 0 & 0 & 0 & 0 & 11 & 0 & 0 & 0 & 0 & 12 \\
\hline & 1.0 & 0 & 0 & 0 & 0 & 0 & 0 & 12 & 0 & 0 & 0 & 12 \\
\hline \multirow[t]{3}{*}{ Potato starch } & 1.0 & 0 & 4 & 1 & 0 & 0 & 0 & 0 & 4 & 3 & 0 & 12 \\
\hline & 1.5 & 0 & 0 & 0 & 0 & 1 & 0 & 0 & 1 & 8 & 2 & 12 \\
\hline & 2.0 & 3 & 0 & 0 & 1 & 0 & 0 & 0 & 0 & 0 & 8 & 12 \\
\hline
\end{tabular}

while increased carrageenan and potato starch additions affected the instrumentally measured colour parameters (with the exception of $b^{*}$ value for carrageenan) and sensory attributes (with the exception of firmness for carrageenan). However, the increasing xanthan additions resulted in changes to both the instrumental and sensory profiles of these chicken breast meat emulsions.

\title{
Uticaj različitih hidrokoloida na profil teksture mesne emulzije od pilećeg mesa
}

\author{
Tomaž Polak, Mateja Lušnic Polak, Igor Lojevec, Lea Demšar
}

A p s tr a k t: Cilj istraživanja je bio da se proizvedu mesne emulzije od pilećeg belog mesa uz dodatak različitih hidrokoloida koji bi mogli imati iste ili bolje teksturne osobine od emulzija proizvedenih uz upotrebu fosfata (E 450-452). Pripremili smo 10 emulzija od mehanički odvojenog pilećeg belog mesa - meso grudi (kao tri eksperimentalna ponavljanja) sa dodatkom: fosfata (kontrola, 0,7\%) $i$ tri različita nivoa karagenana i ksantana $(0,5 \%, 0,8 \%, 1 \%)$ i krompirovog skroba $(1 \%, 1,5 \%, 2 \%)$. Izvršeno je instrumentalno merenje boje (CIE L* $a *, b *$ ) i teksture (analiza profila teksture, test relaksacije stresa), zajedno s procenom senzornih svojstava (deskriptivna analiza). Emulzije od pilećeg belog mesa sa različitim hidrokoloidima značajno su se razlikovale u instrumentalno izmerenim vrednostima za boju, kao i u većini parametara teksture (tvrdoća, kohezivnost, žilavost, lakoća žvakanja, otpornost, F0, I30), i u nekim senzornim osobinama (boja, čvrstoća, ukus). Povećano dodavanje karagenana i krompirovog skroba uticalo je na neke od izmerenih vrednosti za boju i senzorna svojstva, iako izmereni parametri za teksturu nisu bili pod uticajem. Povećano dodavanje ksantana uticalo je na promene u boji, teksturi i senzornim profilima. Mesne emulzije od pilećeg belog mesa sa fosfatom (0,7\%), karagenanom (0,5\%, 0,8\%) i krompirovim skrobom (2,0\%) bile su najsličnije u boji, teksturi i ukusu. Emulzije sa krompirovim skrobom pokazale su trendove, koji nisu bili značajni, za poboljšanje osobina u poređenju sa kontrolnom grupom, zbog intenzivne arome.

Ključne reči: mesne emulzije, fosfat, hidrokoloidi, parametri teksture, senzorna svojstva.

Disclosure statement: No potential conflict of interest was reported by authors.

Acknowledgment: The authors are grateful for financial support from the Ministry of Higher Education, Science and Technology of the Republic of Slovenia, for research programme P4-0234. 


\section{References}

Amako, D. E. N. \& Xiong, Y. L. (2001). Effects of carrageenan on thermal stability of proteins from chicken thigh and breast muscles. Food Research International, 34 (2/3), 247-253. DOI: 10.1016/S0963-9969(00)00161-7

AOAC (1997). Official methods of analysis (16 th ed.), Association of Official Analytical Chemists. Washington, USA.

Ayadi, M. A., Kechaou, A., Makni, I. \& Attia, H. (2009). Influence of carrageenan addition on turkey meat sausages properties. Journal of Food Engineering, 93 (3), 278-283. DOI: 10.1016/j.jfoodeng.2009.01.033

Barbut, S. \& Mittal, G. S. (1992). Use of carrageenans and xanthan gum in reduced fat in breakfast sausages. Lebensmittel-Wissenschaft und Technologie, 25 (6), 509-513.

Bater, B., Descamps, O. \& Maurer, A. J. (1992). Quality characteristics of hydrocolloid-added oven-roasted turkey breasts. Journal of Food Science, 57 (5), 1068-1070. DOI: $10.1111 / \mathrm{j} .1365-2621.1992 . t b 11265 . x$

BeMiller, J. N. \& Huber, K. C (2011). Carbohydrates. Fennema's food chemistry ( $4^{\text {th }}$ ed.), CRC Press. London, UK.

Bourne, M. C. (1978). Texture profile analysis. Food Technology, 32, 62-66.

Brewer, M. S. (2012). Reducing the fat content in ground beef without sacrificing quality: a review. Meat Science, 91 (4), 385-395. DOI: 10.1016/j.meatsci.2012.02.024

Chun, J. Y., Choi, M. J., Min, S.G. \& Hong, G.P. (2014). Effects of binders combined with glucono- $\delta$-lactone on the quality characteristics of pressure-induced cold-set restructured pork. Meat Science, 98 (2), 158-163. DOI: 10.1016/j.meatsci.2014.05.032

Cierach, M., Modzelewska-Kapitula, M. \& Szacilo, K. (2009). The influence of carrageenan on the properties of low-fat frankfurters. Meat Science, 82 (3), 295-299. DOI: 10.1016/j.meatsci.2009.01.025

de Ávila, M. D. R., Cambero, M. I., Ordóñez, J. A., Hoz, L. de la \& Herrero, A. M. (2014). Rheological behaviour of commercial cooked meat products evaluated by tensile test and texture profile analysis (TPA). Meat Science, 98 (2), 310-315. DOI: 10.1016/j.meatsci.2014.05.003

Ellam, T. J. \& Chico, T. J. A. (2012). Phosphate: The new cholesterol? The role of the phosphate axis in non-uremic vascular disease. Atherosclerosis, 220 (2), 310-318. DOI: 10.1016/j.atherosclerosis.2011.09.002

Feiner, G. (2006). Meat products handbook. Practical science and technology, Woodhead Publishing Limited, Cambridge, England.

Fonseca, B., Kuri, V., Zumalacárregui, J. M., Fernández-Diez, A., Salvá, B. K., Caro, I., Osorio, M. T., Mateo, J. (2011). Effect of the use of a commercial phosphate mixture on selected quality characteristics of 2 Spanish-style dry-ripened sausages. Journal of Food Science, 76, S300-S305. DOI: 10.1016/j.meatsci.2014.01.014

Gasperlin, L., Skvarca, M., Zlender, B., Lusnic, M. \& Polak, T. (2014). Quality assessment of Slovenian Krvavica, a traditional blood sausage: sensory evaluation. Journal of Food Processing and Preservation, 38 (1), 97-105. DOI: 10.1111/j.1745-4549.2012.00750.x
Gao, X. Q., Hao, X. Z., Xiong, G. H., Ge, Q. F., Zhang, W. G., Zhou, G. H. \& Yue, X. B. (2016). Interaction between carrageenan/soy protein isolates and salt-soluble meat protein. Food and Bioproducts Processing, 100 (part A), 47-53. DOI: 10.1016/j.fbp.2016.06.014

Golob, T., Jamnik, M., Bertoncelj, J. \& Dobersek, U. (2005). Sensory analysis: methods and assessors. Acta Agriculturae Slovenica, 85 (1), 55-66.

Herrero, A. M., Heia, K. \& Careche, M. (2004). Stress relaxation test for monitoring post mortem textural changes of ice-stored cod (Gadus morhua L). Journal of Food Science, 69 (4), 178-182. DOI: 10.1111/j.1365-2621.2004. tb06344.x

Hsu, S. Y. \& Chung, H. Y. (2001). Effects of $\phi$-carrageenan, salt, phosphates and fat on qualities of low fat emulsified meatballs. Journal of Food Engineering, 47 (2), 115-121. DOI: $10.1016 / \mathrm{S} 0260-8774(00) 00106-0$

Inguglia, E. S., Zhang, Z., Tiwari, B. K., Kerry, J. P. \& Burgess, C. M. (2017). Salt reduction strategies in processed meat products - a review. Trends in Food Science and Technology, 59, 70-78. DOI: 10.1016/j.tifs.2016.10.016

ISO 8589 (2007). Sensory analysis - general guidance for the design of test rooms, International Organization for Standardization, Geneva, Switzerland.

Liu, H., Xiong, Y. L., Jiang, L. \& Kong, B. (2008). Fat reduction in emulsion sausage using an enzyme-modified potato starch. Journal of the Science of Food and Agriculture, 88, 1632-1637. DOI: 10.1002/jsfa.3260

Marchetti, L., Andrés, S. C. \& Califano A. N. (2013). Textural and thermal properties of low-lipid meat emulsions formulated with fish oil and different binders. LWT-Food Science and Technology, 51 (5), 514-523. DOI: 10.1016/j. lwt.2012.12.006

Mittal, G. S. \& Barbut S. (1994). Effects of carrageenans and xanthan gum on the texture and acceptability of low fat frankfurters. Journal of Food Processing and Preservation, 18 (3), 201-216. DOI: 10.1111/j.1745-4549.1994.tb00844.x

Morales, R., Guerrero, L., Serra, X. \& Gou, P. (2007). Instrumental evaluation of defective texture in dry-cured hams. Meat Science, 76 (3), 536-542. DOI: 10.1016/j.meatsci.2007.01.009

Palaniraj, A. \& Jayaraman, V. (2011). Production, recovery and applications of xanthan gum by Xanthomonas campestris. Journal of Food Engineering, 106, 1-12. DOI: 10.1016/j.jfoodeng.2011.03.035

Peleg, M. \& Pollak, N. (1982). The problem of equilibrium conditions in stress relaxation analyses of solid foods. Journal of Texture Studies, 13 (1), 1-11. DOI: 10.1111/ j.1745-4603.1982.tb00873.x

Pietrasik, Z. (2003). Binding and textural properties of beef gels processed with $\mathrm{j}$-carrageenan, egg albumin and microbial transglutaminase. Meat Science, 63 (3), 317-324. DOI: $10.1016 / \mathrm{S} 0309-1740(02) 00088-8$

Pietrasik, Z. \& Duda, Z. (2000). Effect of fat content and soy protein/ carrageenan mix on the quality characteristics of comminuted, scalded sausages. Meat Science, 56 (2), 181-188. DOI: 10.1016/S0309-1740(00)00038-3 
Pons, M. \& Fiszman, S. M. (1996). Instrumental texture profile analysis with particular reference to gelled systems. Journal of Texture Studies, 27 (6), 597-624. DOI: 10.1111/ j.1745-4603.1996.tb00996.x

Purkayastha, S. \& Peleg, M. (1986). Comparison between projected mechanical equilibrium conditions of selected food materials in stress relaxation and creep. Journal of Texture Studies, 17 (4), 433-444. DOI: 10.1111/ j.1745-4603.1986.tb00563.x

European Union (2008). Regulation (EC) No 1333/2008 of the European Parliament and of the Council of 16 December 2008 on food additives. Official Journal of the European Union, 51 (L 354), 16-33.

Sebranek, J. G. (2009). Basic curing ingredients. Tarte, R. (Ed.), Ingredients in meat products, Springer, Wisconsin, USA.

Paper received: 2.10 .2018 .

Paper accepted: 21.11.2018.
Skinner, G. E. \& Rao V. N. M. (1986). Linear viscoelastic behaviour of frankfurters. Journal of Texture Studies 17 (4), 421-432. DOI: 10.1111/j.1745-4603.1986.tb00562.x

Tamsen, M., Shekarchizadeh, H. \& Soltanizadeh, N. (2018). Evaluation of wheat flour substitution with amaranth flour on chicken nugget properties. LWT-Food Science and Technology, 91, 580-587. DOI: 10.1016/j. lwt.2018.02.001

Trius, A., Sebranek, J. G., Rust, R. E. \& Carr, J. M. (1994). Low fat bologna and beaker sausage: effects of carrageenans and chloride salts. Journal of Food Science, 59 (5), 941-945. DOI: 10.1111/j.1365-2621.1994.tb08163.x

Xiong, Y. L., Noel, D. C. \& Moody, W. G. (1999). Textural and sensory properties of low-fat beef sausages with added water and polysaccharides as affected by $\mathrm{pH}$ and salt. Journal of Food Science, 64 (3), 550-554. DOI: 10.1111/ j.1365-2621.1999.tb15083.x 